\title{
Assessment of Awareness and Knowledge of Oral Cancer Among Tobacco-Using Dental Patients
}

\author{
Gaye Keser ${ }^{1}$, Merve Ozturk ${ }^{2}$, Filiz Namdar Pekiner ${ }^{2}$ \\ ${ }^{1}$ Department of Oral and Maxillofacil Radiology, Faculty of Dentistry, Marmara University, Turkey \\ ${ }^{2}$ Department of Oral and Maxillofacial Surgery, Faculty of Dentistry, Istanbul University, Turkey \\ Correspondence Author: Gaye Keser \\ E-mail: gayekeser@hotmail.com \\ Received: $01.08 .2020 \quad$ Accepted: 29.05 .2021
}

\begin{abstract}
Objective: The aim of this study is assesment of awareness and knowledge of oral cancer in a group of tobacco users.

Methods: The study group consisted of 100 adult patients aged 18 years and over who applied to Marmara University Faculty of Dentistry Oral and Maxillofacial Radiology Clinic for routine examination. The patients were asked to complete a 16-point questionnaire evaluating the effects of smoking on oral cancer.

Results: The participants in our study identified oral cancer symptoms as swelling / mass formation (60\%), wound in mouth (58\%), loss of sensation (39\%) and pain (38\%). There was statistically significant difference between the responses given to "What are the causes of oral cancer?", "what are the symptoms of oral cancer?" and "What are the diagnostic methods for oral cancer?" between women and men ( $p$ $<0.05)$. The rate of responding to the question "What do you think are the causes of oral cancer?" as "alcohol use" in women (63.3\%) was significantly higher than men $(39.2 \%)(p=0.027 ; p<0.05)$. There was no statistically significant difference between genders regarding "smoking" and "chewing tobacco" as oral cancer factor ( $p>0.05)$.

Conclusion: It is concluded that women smoker individiuals have more awareness, knowledge level and positive attitudes about oral cancer compared to men. Increasing level of knowledge of individuals about oral cancer, routine examination of individuals at high risk group and development of national policies with this purpose can make a contribution to improve the level of consciousness.
\end{abstract}

Keywords: Oral Cancer, Smoking, Public Awareness

\section{INTRODUCTION}

Oral cavity cancers were the seventh most commonly occurring cancer and, in terms of mortality, the ninth deadliest by cancer site in the world as stated by World Cancer Report 2014 (1-6). Besides skin and thyroid cancers, after larynx carcinoma, oral cavity cancers are supposed to be the second most common head and neck malignancy in Turkey (7). Oral squamous cell carcinoma represents one of the most common but scarcely known malignancies worldwide. The etiology of oral squamous cell carcinoma is strongly related to lifestyle habits and behavior, especially tobacco smoking and alcohol abuse.

Tobacco and alcohol use is the primary risk factors for oral cancer in patients over the age of 45 years $(8,9)$. Low consumption of fruits and vegetables, immunodeficiency exposure to the sun, socio-economic status, and infection with human papilloma virus (HPV) are some of the other risk factors for oral cancers (10-12). Previous studies in literature revealed that the incidence of oral cancer increases with smoking tobacco, older age, and alcohol consumption $(1,5$ 13,14).

Epidemiological studies have shown that the risk of developing cancer in smokers is 5-9 times higher than in nonsmokers. This rate may increase to 17 times in individuals consuming more than 80 cigarettes per day. The risk of having a second malignant upper respiratory disease increases by 2 to 6 times in patients who have been treated and continue smoking (15).

In a study conducted by Formosa et al. (16), a selfadministered questionnaire was designed and consisted of the questions to ascertain socio-demographic information, awareness and knowledge of oral and pharyngeal cancer. The study revealed that $52.3 \%$ of the respondents were aware of the existence of oral cancer. Of those who were aware of oral cancer, $92 \%$ agreed or strongly agreed that smoking is a strong risk factor for oral cancers. 
Peker et al. (17) evaluated levels of public awareness and knowledge about early signs and risk factors of oral cancer among a group of dental patients in Turkey. The results of the study reveals that $79.2 \%$ of the participants were unaware of the early signs related to oral cancer and $29.9 \%$ of them were unaware of risk factors of the disease. There were no statistically significant differences between age, gender, and education levels for awareness of risk factors. Therefore, the primary aim of this study was to assess the awareness and knowledge of oral cancers and smoking as a risk factor among group of smokers.

\section{MATERIALS AND METHODS}

The study protocol of this thesis study was approved by Marmara University School of Medicine Non-Interventional Clinical Research Ethics Committee on 14.06.2019 with protocol number 09.2019.553. This research was carried out in Marmara University Faculty of Dentistry, İstanbul, Turkey. In this study, the study group consisted of 100 patients aged 18 years and over who applied to the Department of Oral and Maxillofacial Radiology for routine examination. A questionnaire consisting of 16 questions evaluating oral cancer information and smoking, including questions about sociodemographic examination, was administered to the study group.

\section{Statistical Analysis}

IBM SPSS Statistics 22.0 (IBM SPSS, Turkey) program is used for statistical analysis. Descriptive statistical methods (frequency) as well as qualitative data were compared using the Chi-Square test, Fisher's Exact Chi-Square test, Continuity (Yates) Correction, and Fisher's Freeman Halton test. Significance was assessed at $p<0.05$ level.

\section{RESULTS}

The study was performed on 100 patients, over 18 years old, and 49 (49.0\%) female and 51 (51.0\%) male were included (Table 1).

In the study, $75 \%$ of the participants considered the age group most affected by oral cancer as 40 years and older, while $19 \%$ considered young adults and $6 \%$ considered childhood (Table 2). The rates of participation in the statement "causes of oral cancers" are 78\% smoking, 55\% chewing tobacco, 51\% drinking alcohol, $43 \%$ genetic predisposition, $41 \%$ unhealthy nutrition, $41 \%$ chemicals, $39 \%$ irregular life and stress, $33 \%$ decayed teeth, $27 \%$ inappropriate dentures, $10 \%$ other answers and $10 \%$ of the participants have no idea (Figure 1 ). In addition, it is reported that $47 \%$ of smoker patients in our study get information about oral cancer from their dentists. The participants stated that they would quit smoking (70\%), eat well (52\%), take medication (20\%) for prevention of oral cancer. There was no statistically significant difference between the amount of daily cigarette smoking by gender (p>0 .05) (Table 3) (Figure 2).
Table 1: Distribution of demographic characteristics

\begin{tabular}{|c|c|c|c|}
\hline & & $n$ & $\%$ \\
\hline \multirow[t]{2}{*}{ Gender } & Woman & 49 & 49.0 \\
\hline & Male & 51 & 51.0 \\
\hline \multirow[t]{5}{*}{ Age } & $18-20$ years & 4 & 4.0 \\
\hline & $20-30$ years & 56 & 56.0 \\
\hline & $30-40$ years & 24 & 24.0 \\
\hline & $40-50$ years & 12 & 12.0 \\
\hline & Over 50 years & 4 & 4.0 \\
\hline \multirow[t]{2}{*}{ Marital status } & Married & 37 & 37.0 \\
\hline & Single & 63 & 63.0 \\
\hline \multirow[t]{4}{*}{ Education } & Primary education or lower & 10 & 10.0 \\
\hline & Secondary education & 9 & 9.0 \\
\hline & High school & 19 & 19.0 \\
\hline & College & 62 & 62.0 \\
\hline \multirow[t]{8}{*}{ Occupation } & Retired & 4 & 4.0 \\
\hline & Self-employed & 30 & 30.0 \\
\hline & Artisan & 7 & 7.0 \\
\hline & Merchant & 2 & 2.0 \\
\hline & Mid-level executive & 8 & 8.0 \\
\hline & Officer & 14 & 14.0 \\
\hline & Employee & 14 & 14.0 \\
\hline & Housewife & 21 & 21.0 \\
\hline \multirow{2}{*}{$\begin{array}{l}\text { M e d i c a l } \\
\text { condition }\end{array}$} & Healthy & 82 & 82.0 \\
\hline & Has a medical issue & 18 & 18.0 \\
\hline \multirow[t]{6}{*}{ Diseases } & Other & 11 & 61.0 \\
\hline & Diabetes & 2 & 11.1 \\
\hline & Diabetes + Other & 1 & 5.6 \\
\hline & Diabetes + Hypertension & 1 & 5.6 \\
\hline & Hypertension & 2 & 11.1 \\
\hline & Cardiovascular system diseases & 1 & 5.6 \\
\hline \multirow{3}{*}{$\begin{array}{l}\mathrm{S} \mathrm{m} \text { o } \mathrm{k} \text { i } \mathrm{n} \mathrm{g} \\
\text { duration }\end{array}$} & $<5$ years & 40 & 40.0 \\
\hline & $6-10$ years & 20 & 20.0 \\
\hline & More than 10 years & 40 & 40.0 \\
\hline \multirow{3}{*}{$\begin{array}{l}\text { Daily cigarette } \\
\text { use }\end{array}$} & $<1$ package per day & 62 & 62.0 \\
\hline & 1 package per day & 32 & 32.0 \\
\hline & More than 1 package per day & 6 & 6.0 \\
\hline \multirow{7}{*}{$\begin{array}{l}\text { Diseases caused } \\
\text { by smoking }\end{array}$} & Does not cause any disease & 4 & 4 \\
\hline & COPD & 80 & 80 \\
\hline & Lung cancer & 86 & 86 \\
\hline & Coronary heart diseases & 65 & 65 \\
\hline & Pancreatic cancer & 28 & 28 \\
\hline & Oral cancer & 71 & 71 \\
\hline & Other & 21 & 21 \\
\hline
\end{tabular}

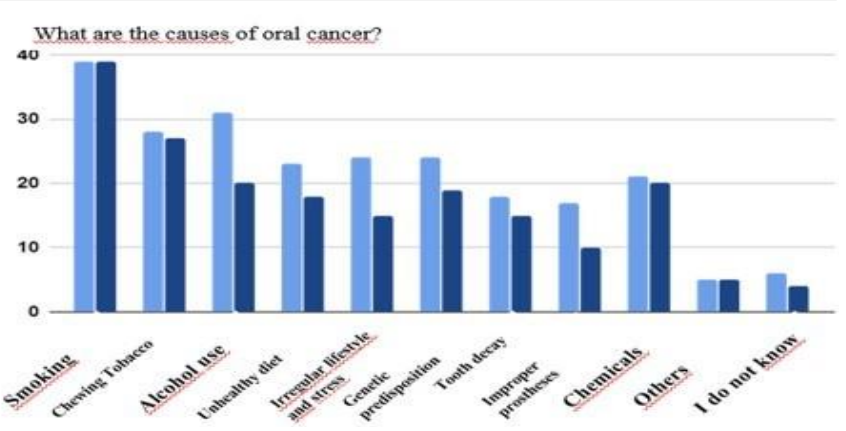

Figure 1.Distribuiton of participants answers for causes of oral cancer. 
Table 2: Evaluation of information on oral cancer

\begin{tabular}{|c|c|c|c|}
\hline & & $\mathbf{n}$ & $\%$ \\
\hline \multirow{3}{*}{$\begin{array}{l}\text { Age group most } \\
\text { affected by oral } \\
\text { cancer }\end{array}$} & Children & 6 & 6 \\
\hline & Young Adults & 19 & 19 \\
\hline & 40 years and older & 75 & 75 \\
\hline \multirow{11}{*}{$\begin{array}{l}\text { Causes of oral } \\
\text { cancer }\end{array}$} & Smoking & 78 & 78 \\
\hline & Chewing Tobacco & 55 & 55 \\
\hline & Alcohol use & 51 & 51 \\
\hline & Unhealthy diet & 41 & 41 \\
\hline & Irregular lifestyle and stress & 39 & 39 \\
\hline & Genetic predisposition & 43 & 43 \\
\hline & Tooth decay & 33 & 33 \\
\hline & Improper prostheses & 27 & 27 \\
\hline & Chemicals & 41 & 41 \\
\hline & Other & 10 & 10 \\
\hline & I do not know & 10 & 10 \\
\hline \multirow{7}{*}{$\begin{array}{l}\text { Symptoms of oral } \\
\text { cancer }\end{array}$} & Wound in mouth & 58 & 58 \\
\hline & Swelling / mass formation & 60 & 60 \\
\hline & Pain & 38 & 38 \\
\hline & Bleeding of the gums & 27 & 27 \\
\hline & Loss of sensation & 39 & 39 \\
\hline & Other & 11 & 11 \\
\hline & I do not know & 27 & 27 \\
\hline \multirow{5}{*}{$\begin{array}{l}\text { Oral cancer } \\
\text { diagnosis methods }\end{array}$} & Regular inspection and control & 68 & 68 \\
\hline & Non-neglect of wounds & 48 & 48 \\
\hline & $\begin{array}{l}\text { Consult a doctor if there is a } \\
\text { problem }\end{array}$ & 61 & 61 \\
\hline & Other & 5 & 5 \\
\hline & I do not know & 16 & 16 \\
\hline \multirow{5}{*}{$\begin{array}{l}\text { Oral cancer } \\
\text { prevention methods }\end{array}$} & To use medicine & 20 & 20 \\
\hline & Stop smoking & 70 & 70 \\
\hline & Healthy eating & 52 & 52 \\
\hline & Other & 10 & 10 \\
\hline & I do not know & 23 & 23 \\
\hline \multirow{7}{*}{$\begin{array}{l}\text { The consequences } \\
\text { of oral cancer }\end{array}$} & Tooth loss & 47 & 47 \\
\hline & Jaw-related damage / tissue loss & 62 & 62 \\
\hline & $\begin{array}{l}\text { Spread / affection of lymph } \\
\text { nodes }\end{array}$ & 45 & 45 \\
\hline & Inability to heal & 38 & 38 \\
\hline & Death / life hazard & 51 & 51 \\
\hline & Other & 7 & 7 \\
\hline & I do not know & 24 & 24 \\
\hline \multirow{5}{*}{$\begin{array}{l}\text { Sources of } \\
\text { information on oral } \\
\text { cancer }\end{array}$} & Family & 9 & 9 \\
\hline & Dentist & 47 & 47 \\
\hline & Press (television, internet etc.) & 32 & 32 \\
\hline & Other (friends, patient) & 24 & 24 \\
\hline & $\begin{array}{l}\text { I do not have any information } \\
\text { sources }\end{array}$ & 36 & 36 \\
\hline
\end{tabular}

How many packs of cigarettes do you smoke per day?

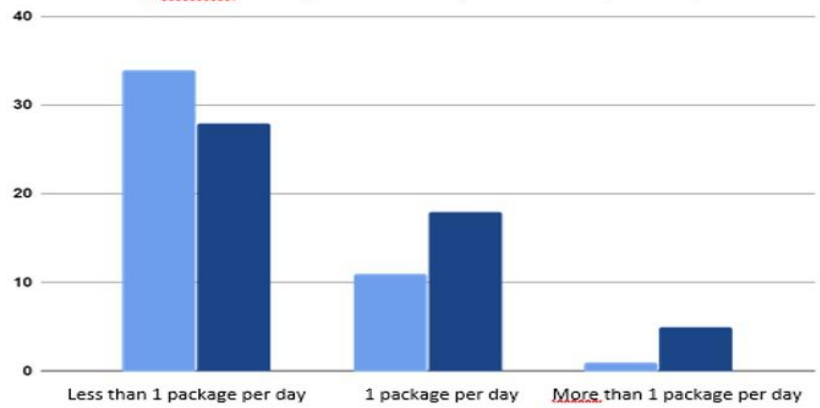

Figure 2. Assessment of daily smoking by gender
Table 3: Assessment of daily smoking by gender

\begin{tabular}{|l|l|l|l|}
\hline Daily cigarette use & Woman & Male & p \\
\cline { 2 - 4 } & $\mathrm{n}(\%)$ & $\mathrm{n}(\%)$ & \\
\hline Less than 1 package per day & $34(69.4 \%)$ & $28(54.9 \%)$ & 0.182 \\
\hline 1 package per day & $14(28.6 \%)$ & $18(35.3 \%)$ & \\
\hline More than 1 package per day & $1(\% 2)$ & $5(9.8 \%)$ & \\
\hline
\end{tabular}

\section{Fisher Freeman Halton Test}

Woman participants (63.3\%) who answered "alcohol use" to the question "What do you think causes oral cancer?" is highly statistically significant than that of man patients (39.2 \%) $(p=0.027, p<0.05)$. To the question "What do you think are the symptoms of oral cancer?", woman patients rate of answering "wound in mouth" (69.4\%) is stastistically higher than man participants $(47,1 \%)(p=0,040, p<0,05)$. There was no statistically significant difference between genders in terms of the answers "swelling / mass formation", "pain" , "gingival bleeding" and "loss of sensation" as a sign of oral cancer $(p>0,05)$. The rate of woman patients "referring to a doctor when there is a symptom" as a method of diagnosis of oral cancer $(73,5 \%)$ was statistically higher than that of men $(49 \%)(p=0,021 ; p<0,05)$. There was no statistically significant difference between the genders in terms of answers to the questions "What do you think are the methods of prevention from oral cancers?", "What do you think are the consequences of oral cancer?, "What are your sources of information about oral cancers?" ( $p>0,05)$ (Table 4).

Table 4: Evaluation of information on oral cancer by gender

\begin{tabular}{|c|c|c|c|c|}
\hline & & Woman & Male & p \\
\hline & & n (\%) & $n(\%)$ & \\
\hline Age group & Childhood & $4(8.2 \%)$ & $2(3.9 \%)$ & ${ }^{1} 0.446$ \\
\hline most affected & Young Adult & $11(22.4 \%)$ & $8(15.7 \%)$ & \\
\hline by oral cancer & $\begin{array}{l}40 \text { years and } \\
\text { older }\end{array}$ & 34 (69.4\%) & 41 (80.4\%) & \\
\hline & Smoking & 39 (79.6\%) & 39 (76.5\%) & ${ }^{2} 0.892$ \\
\hline Causes of oral & Chewing Tobacco & $28(57.1 \%)$ & $27(52.9 \%)$ & ${ }^{3} 0.673$ \\
\hline cancer & Alcohol use & $31(63.3 \%)$ & $20(39.2 \%)$ & ${ }^{2} 0.027$ * \\
\hline & Unhealthy eating & $23(46.9 \%)$ & $18(35.3 \%)$ & ${ }^{2} 0.327$ \\
\hline & $\begin{array}{l}\text { Irregular life and } \\
\text { stress }\end{array}$ & $24(49 \%)$ & 15 (29.4\%) & ${ }^{2} 0.072$ \\
\hline & $\begin{array}{l}\text { Genetic } \\
\text { predisposition }\end{array}$ & $24(49 \%)$ & 19 (37.3\%) & ${ }^{2} 0.326$ \\
\hline & Tooth decay & $18(36.7 \%)$ & 15 (29.4\%) & ${ }^{2} 0.572$ \\
\hline & $\begin{array}{l}\text { Improper } \\
\text { prostheses }\end{array}$ & $17(34.7 \%)$ & 10 (19.6\%) & ${ }^{2} 0.141$ \\
\hline & Chemicals & 21 (42.9\%) & $20(39.2 \%)$ & ${ }^{3} 0.711$ \\
\hline & Other & $5(10.2 \%)$ & $5(9.8 \%)$ & ${ }^{4} 1.000$ \\
\hline & I do not know & $6(12.2 \%)$ & 4 (7.8\%) & ${ }^{4} 0.521$ \\
\hline & Wound in mouth & $34(69.4 \%)$ & $24(47.1 \%)$ & ${ }^{2} 0.040$ * \\
\hline $\begin{array}{l}\text { Symptoms of } \\
\text { oral cancer }\end{array}$ & $\begin{array}{l}\text { Swelling / mass } \\
\text { formation }\end{array}$ & $33(67.3 \%)$ & 27 (52.9\%) & ${ }^{2} 0.206$ \\
\hline & Pain & $21(42.9 \%)$ & $17(33.3 \%)$ & ${ }^{2} 0.438$ \\
\hline & $\begin{array}{l}\text { Bleeding of the } \\
\text { gums }\end{array}$ & $17(34.7 \%)$ & $10(19.6 \%)$ & ${ }^{2} 0.141$ \\
\hline & Loss of sensation & $23(46.9 \%)$ & $16(31.4 \%)$ & ${ }^{2} 0.164$ \\
\hline & Other & $7(14.3 \%)$ & $4(7.8 \%)$ & ${ }^{2} 0,478$ \\
\hline & I do not know & $9(18.4 \%)$ & $18(35.3 \%)$ & ${ }^{2} 0.093$ \\
\hline
\end{tabular}




\begin{tabular}{|c|c|c|c|c|}
\hline \multirow{5}{*}{$\begin{array}{l}\text { Oral cancer } \\
\text { diagnosis } \\
\text { methods }\end{array}$} & $\begin{array}{l}\text { Regular } \\
\text { inspection and } \\
\text { control }\end{array}$ & 36 (73.5\%) & $32(62.7 \%)$ & ${ }^{2} 0,350$ \\
\hline & $\begin{array}{l}\text { Non-neglect of } \\
\text { wounds }\end{array}$ & $32(65.3 \%)$ & $16(31.4 \%)$ & ${ }^{2} 0.001$ * \\
\hline & $\begin{array}{l}\text { Consult a doctor } \\
\text { if there is a } \\
\text { problem }\end{array}$ & 36 (73.5\%) & 25 (49\%) & ${ }^{2} 0.021 *$ \\
\hline & Other & $4(8.2 \%)$ & 12) & ${ }^{4} 0,200$ \\
\hline & I do not know & $5(10.2 \%)$ & $11(21.6 \%)$ & ${ }^{2} 0.202$ \\
\hline \multirow{5}{*}{$\begin{array}{l}\text { Oral cancer } \\
\text { prevention } \\
\text { methods }\end{array}$} & To use medicine & $9(18.4 \%)$ & $11(21.6 \%)$ & ${ }^{2} 0.881$ \\
\hline & Stop Smoking & 38 (77.6\%) & 32 (62.7\%) & ${ }^{2} 0.162$ \\
\hline & Eat well & $28(57.1 \%)$ & $24(47.1 \%)$ & ${ }^{3} 0.313$ \\
\hline & Other & $5(10.2 \%)$ & $5(9.8 \%)$ & ${ }^{4} 1.000$ \\
\hline & I do not know & $9(18.4 \%)$ & $14(27.5 \%)$ & ${ }^{2} 0.400$ \\
\hline \multirow{7}{*}{$\begin{array}{l}\text { Oral cancer } \\
\text { results }\end{array}$} & Tooth loss & $25(51 \%)$ & 22 (43.1\%) & ${ }^{3} 0.430$ \\
\hline & $\begin{array}{l}\text { Jaw-related } \\
\text { damage / tissue } \\
\text { loss }\end{array}$ & 31 (63.3\%) & $31(60.8 \%)$ & ${ }^{2} 0.961$ \\
\hline & $\begin{array}{l}\text { Spread / affect } \\
\text { the lymph system }\end{array}$ & 24 (49\%) & 21 (41.2\%) & ${ }^{3} 0.433$ \\
\hline & Inability to heal & $22(44.9 \%)$ & $16(31.4 \%)$ & ${ }^{3} 0.164$ \\
\hline & $\begin{array}{l}\text { Death / life } \\
\text { hazard }\end{array}$ & 24 (49\%) & 27 (52.9\%) & ${ }^{3} 0.692$ \\
\hline & Other & $4(8.2 \%)$ & $3(5.9 \%)$ & ${ }^{4} 0.712$ \\
\hline & I do not know & $12(24.5 \%)$ & $12(23.5 \%)$ & ${ }^{2} 1.000$ \\
\hline \multirow{5}{*}{$\begin{array}{l}\text { Sources of } \\
\text { information } \\
\text { on oral cancer }\end{array}$} & Family & $4(8.2 \%)$ & $5(9.8 \%)$ & ${ }^{4} 1.000$ \\
\hline & Dentist & $23(46.9 \%)$ & $24(47.1 \%)$ & ${ }^{3} 0.990$ \\
\hline & $\begin{array}{l}\text { Press (television, } \\
\text { internet etc.) }\end{array}$ & $15(30.6 \%)$ & 17 (33.3\%) & ${ }^{2} 0.938$ \\
\hline & $\begin{array}{l}\text { Other (friends, } \\
\text { patient) }\end{array}$ & $12(24.5 \%)$ & $12(23.5 \%)$ & ${ }^{2} 1.000$ \\
\hline & $\begin{array}{l}\text { I do not have } \\
\text { any information } \\
\text { sources }\end{array}$ & $18(36.7 \%)$ & $18(35.3 \%)$ & ${ }^{2} 1.000$ \\
\hline
\end{tabular}

${ }^{1}$ Fisher Freeman Halton Test ${ }^{2}$ Continuity (yates) correction ${ }^{3}$ Chi-square Test ${ }^{4}$ Fisher's Exact Test

${ }^{*} p<0.05$

\section{DISCUSSION}

Oral cancer is defined as cancers arising on the lip, oral cavity, and oropharynx and it has been estimated that changes in the world's demography would result in an increase of incidence rates of oral cancer by $62 \%$ in $2035(18,19)$. Consumption of cigarettes with high concentrations of alcohol increases the risk of oral cancer 6-15 times in people over 50 years of age (20). Public awareness on oral and cancer and potentially malignant disorders and their risk factors is crucial for prevention and early detection of oral cancer.

Wimardhani et. al. (18), investigated the awareness of oral cancer among adults in Jakarta and a previously-tested questionnaire on 1000 adults in Jakarta was used in their study. They reported that only $53.2 \%$ of participants were aware of oral cancer and all of the smoker adults knew that tobacco increased the risk for oral cancer. Moreover, health warnings were the main source of information about oral cancer. In our study, $78 \%$ of participants considered smoking as a cause of oral cancer and $47 \%$ of the patients stated that dentists are the sources of information for their oral cancer awareness.

In another study, Varela-Centelles et al. (21), portrayed the level of oral cancer knowledge and awareness in a Spanish general population. An anonymous questionnaire applied to 1,041 individuals and it is reported that $72 \%$ of the participants were familiar with oral cancer. Participants were also asked about the main signs or symptoms of oral cancer, and the most frequently (22\%) mentioned as the first warning sign was a non-healing ulcer. Tobacco smoking generally was recognised as the most important (57\%) risk factor for oral cancer.

Formosa et al. (22), investigated public awareness/knowledge on oral cancer in Australia and over half (52.3\%) of the respondents were aware that cancer could occur in the mouth and the gender did not influence the awareness ( $X 2=1.466$, $\mathrm{p}=0.226$ ). In our study, $75 \%$ of the participants considered the age group most affected by oral cancer as 40 years and older, while $19 \%$ considered young adults and $6 \%$ considered childhood. Formosa et al. reported that of those who were aware of oral cancer, $92 \%$ agreed that smoking is a strong risk factor for oral cancer. They have also stated that the greatest awareness was found among the youngest age group 20$39(61.4 \%)$ while the lowest (39.8\%) was found among the respondents over the age of 60 years. In terms of the source of information for being aware of oral cancer the study found that mass media (newspapers, television, and radio) play a sizeable role being the leading source of information. It was also evident that dentist has been the second highest source of information. Similarly, $47 \%$ of smoker patients in our study gets information about oral cancer from their dentists. The present study revealed that the knowledge on the signs of oral cancer was poor in that only below $50 \%$ were aware of different presentations of cancer in the mouth. Similarly, in our study, $58 \%$ of the partidcipants stated wounds in mouth, and $60 \%$ of them stated mass formation as main symptoms of oral cancer. Park et al. (23), in their study in Western Australia also found compatible results in that $49 \%$ of the participants did not know any signs or symptoms of oral cancer.

In a study conducted by Aydın (24), dental patients' oral cancer awareness and attitudes were assesed. In their study $44 \%$ of the study participants had never heard of oral cancer, yet smoking was the most frequently identified cause and sore in the mouth was the most frequently identified symptom. In our study, smoking took the first place with $78 \%$ and followed by $55 \%$ tobacco chewing (55\%). Their study also reported that $4 \%$ of the participants would consult a doctor when a symptom is present, similiar with our study (5\%). In addition, the rate of woman patients "referring to a doctor when there is a symptom" as a method of diagnosis of oral cancer $(73.5 \%)$ was statistically higher than that of men (49\%) $(p=0,021 ; p<0.05)$ in our present study.

Peker and Alkurt (17) also reported the levels of public awareness and knowledge about early signs and risk factors of oral cancer among a group of 1022 dental patients in 
Turkey and found that in total $60.7 \%$ of participants had never heard of oral cancer. While $79.2 \%$ of the participants were unaware of the early signs related to oral cancer, $29.9 \%$ of them were unaware of risk factors of the disease. The risk factors associated with oral cancer that were most often correctly identified by the participants were smoking (57.6\%, $n=589)$; regular consumption of alcohol $(27.9 \%$, $\mathrm{n}=285)$; excessive exposure to sunlight (15\%, $n=153)$; eating hot, spicy foods $(9.9 \%, \mathrm{n}=101)$; and biting the cheek or lip $(6.8 \%, \mathrm{n}=69)$ respectively. There were no statistically significant differences between age, gender, and education levels for awareness of risk factors. In our study the rates of participation in the statement "causes of oral cancers" are 78\% smoking, 55\% chewing tobacco, 51\% drinking alcohol, $43 \%$ genetic predisposition, $41 \%$ unhealthy nutrition, $41 \%$ chemicals, 39\% irregular life and stress, 33\% decayed teeth, $27 \%$ inappropriate dentures, $10 \%$ other answers and $10 \%$ of the participants have no idea. Moreover, woman participants (63.3\%) who answered "alcohol use" to the question "What do you think causes oral cancer?" is highly statistically significant than that of man patients (39.2\%) $(p=0.027, p<0.05)$. To the question "What do you think are the symptoms of oral cancer?", woman patients rate of answering "wound in mouth" (69.4\%) is stastistically higher than man participants (47.1\%) $(p=0.040, p<0.05)$.

This study's reliance on self-reported data may be seen as a limitation. Respondents may exaggerate, or they may underreport the severity or frequency of conditions. Patients might also simply be mistaken or misremember the material covered by the survey.

\section{CONCLUSION}

It is concluded that in comparison to men, women smokers have higher levels of understanding, education, and optimistic attitudes toward oral cancer. However, the issue of delayed diagnosis can be addressed by patient self-examination of early symptoms of illness and the development of effective interventions to improve clinician awareness and preventive attitudes. Moreover, a comprehensive knowledge on oral cancer to undergraduates and dental graduates should be given through a review of dental curriculum and formal continued education.

\section{Acknowledgement:}

This study was based on undegraduate thesis of Merve Öztürk.

\section{REFERENCES}

[1] Keser G, Pekiner FN. Assessing Oral Cancer Awareness Among Dental Students. J Cancer Educ 2019; 34(3):512-518.

[2] Jaber MA. Dental practitioner's knowledge, opinions and methods of management of oral premalignancy and malignancy. Saudi Dent J 2011; 23:29-36.
[3] Oliveira JMB, Pinto LO, Lima NGM, Almeida GCM. Oral cancer: assessment of academic dentistry and nursing knowledge as for the risk factors and diagnostic procedures. Rev Bras Canc 2013; 59: 211-218.

[4] Carter LM, Ogden GR. Oral cancer awareness of undergraduate medical and dental students. BMC Med Educ 2007; 15:44-52.

[5] Kebabcıoğlu Ö, Pekiner FN. Assessing oral cancer awareness among dentists. J Cancer Educ. 2017; 33:1020-1026.

[6] Le Campion ACOV, Ribeiro CMB, Luiz RR, da Silva Júnior FF, Barros HCS, Dos Santos KCB et al. Low survival rates of oral and oropharyngeal squamous cell carcinoma. Int J Dent 2017; 5815493.

[7] Düzlü M, Karamert R, Bakkal FK, Cevizci R, Tutar H, Zorlu ME, Dilci A, EravcI FC. The demographics and histopathological features of oral cavity cancers in Turkey. Turk J Med Sci. 2016; 46:1672- 1676.

[8] Rupel K, Ottaviani G, Gobbo M, Poropat A, Zoi V, Zacchigna $S$, Di Lenarda R, Biasotto M. Campaign to Increase Awareness of Oral Cancer Risk Factors Among Preadolescents. J Cancer Educ. 2019; doi: 10.1007/s13187.019.01504-7.

[9] International Agency for Research on Cancer (IARC) Working Group on the Evaluation of Carcinogenic Risk to Humans. 2004. Tobacco smoke and involuntary smoking, Monographs on the evaluation of carcinogenic risk to humans, vol 83 . International Agency for Research on Cancer, Lyon http:// monographs.iarc.fr/ENG/ Monographs/vol83/mono

[10] Husain N, Neyaz A. Human papillomavirus associated head and neck squamous cell carcinoma: controversies and new concepts. J Oral Biol Craniofac Res 2017;7(3):198-205.

[11] Torre LA, Siegel RL, Ward EM, Jemal A. Global cancer incidence and mortality rates and trends-an update. Cancer statistics, Cancer Epidemiol Biomark Prev 2016; 25(1):16-27. https:// doi.org/10.1158/1055-9965.EPI-15-0578.

[12] Güneri P, Epstein JB. Late stage diagnosis of oral cancer: components and possible solutions. Oral Oncol 2014; 50(12):1131-1136.

[13] Varela-Centelles P, Estany-Gestal A, Bugarín-González R, Seoane - Romero JM. Oral cancer awareness in Spain: a pilot study. Oral Dis 2018; 24(1-2):124-127.

[14] Rogers SN, Hunter R, Lowe D. Awareness of oral cancer in the Mersey region. Br J Oral Maxillofac Surg 2011; 49:176-181.

[15] Neville B.W., Day T. A. Oral Cancer and Precancerous Lesions. CA: A Cancer Journal for Clinicians 2009; 2:195-199.

[16] Formosa J, Jenner R, Nguyen-Thi MD, Stephens C, Wilson C, Ariyawardana A. Awareness and Knowledge of Oral Cancer and Potentially Malignant Oral Disorders among Dental Patients in Far North Queensland, Australia. Asian Pac J Cancer Prev 2015; 16:4429-4434.

[17] Peker I, Alkurt MT. Public Awareness Level of Oral Cancer in a Group of Dental Patients. J Contemp Dent Pract 2010; 11:049056.

[18] Wimardhani YS, Warnakulasuriya S, Subita GP, Soegyanto Al, Pradono SA, Patoni N.2019. Public awareness of oral cancer among adults in Jakarta, Indonesia. J Invest Clin Dent 10:e12379.

[19] Shield KD, Ferlay J, Jemal A, et al. The global incidence of lip, oral cavity, and pharyngeal cancers by subsite in 2012. CA Cancer J Clin 2017; 67:51-64.

[20] Özbayrak S, Pekiner FN. 2016. Oral cancers: clinical findings and treatment approaches in point of early diagnosis. Quintessence Publication, i̇stanbul.815493. 
[21] Varela-Centelles P, Estany-Gestal A, Bugarín-González R, Seoane-Romero JM. Oral cancer awareness in Spain: A pilot study. Oral Dis 2018; 24:124-127.

[22] Formosa J, Jenner R, Nguyen-Thi MD, Stephens C, Wilson C, Ariyawardana A. Awareness and Knowledge of Oral Cancer and Potentially Malignant Oral Disorders among Dental Patients in Far North Queensland, Australia. Asian Pac J Cancer Prev 2015; 16:4429-4434.
[23] Park J H, Slack-Smith L, Smith A, et al. Knowledge and perceptions regarding oral and pharyngeal carcinoma among adult dental patients. Aust Dent J 2011; 56, 284-289.

[24] Aydın Ü. Patients' oral cancer awareness and perceptions of oral cancer screening with a fluorescence visualization device. Cumhuriyet Dental Journal 2014; 1:117-128.

How to cite this article: Keser G, Ozturk M, Namdar Pekiner F. Assessment of Awareness and Knowledge of Oral Cancer Among Tobacco-Using Dental Patients. Clin Exp Health Sci 2021; 11: 279-284. DOI: 10.33808/ clinexphealthsci.753980 